Vol 5 No 1 Maret 2018

\title{
Implementasi Tugas Dan Kewenangan Notaris Dalam Membuat Akta Yang Berkaitan Dengan Pertanahan (Studi di Wilayah KerjaNotarisKabupaten Kendal)
}

\author{
Romanda Arif Kurnia*, Umar Ma'ruf*
* Mahasiswa Program Magister (S2) Kenotariatan Fakultas Hukum UNISSULA, Semarang email : romanarief93@gmail.com
** Dosen Fakultas Hukum UNISSULA

\begin{abstract}
ABSTRAK
Tugas dan kewenangan Notaris dalam membuat akta yang berkaitan dengan pertanahan perlu dipahami secara berbeda agar tidak menimbulkan kerancuan. Pertanyaan yang timbul dari problem ini adalah: Bagaimana implementasi tugas dan kewenangan Notaris dalam membuat akta yang berkaitan dengan pertanahan?Apa kelemahan-kelemahan dalam implementasi tugas dan wewenang Notaris dalam pembuatan Akta yang berkaitan dengan pertanahan ? Bagaimana solusi implementasi tugas dan wewenang Notaris dalam pembuatan Akta yang berakitan dengan pertanahan ?

Metode pendekatan menggunakan sosio legal research.Data yang digunakan adalah data primer dan sekunder. Metode pengumpulan data menggunakan wawancara dan studi pustaka. Metode analisis data menggunakan analisis kualitatif.

Permasalahan di analisis dengan teori kepastian hukum dan teori kewenangan: Pertama,Implementasi tugas dan kewenangan Notaris dalam membuat akta yang berkaitan dengan pertanahandipahami secara berbeda, karena; (1) Mengacu Pasal 15 ayat (2) huruf (f) UUJN 2014, maka Notaris secara otomatis adalah pejabat yang berwenang membuat akta tanah. Namun kenyataan di lapangan, Notaris tidak secara otomatis dapat menjadi Pejabat Pembuat Akta Tanah (PPAT) (2) Pada praktik di lapangan, Notaris dapat diangkat menjadi PPAT setelah mengikuti pendidikan dan pelatihan serta dinyatakan lulus yang diselenggarakan oleh BPN.Akan tetapi bahwa dalam hal Notaris membuat akta - akta yang berkaitan dengan pertanahan yang bukan merupakan kewajiban PPAT.Kedua, Kelemahan implementasi tugas dan kewenangan Notaris dalam membuat akta yang berkaitan dengan pertanahan adalah: (a) Konsep ideal implementasi tugas dan kewenangan Notaris menurut UUJN 2014 yaitu seorang Notaris sekaligus PPAT; (2) Praktik implementasi tugas dan kewenagan Notaris di lapangan berbeda dengan UUJN 2014, karena Notaris diangkat menjadi PPAT setelah harus mengikuti pendidikan dan pelatihan serta dinyatakan lulus yang diselenggarakan oleh BPN. Ketiga solusi terkait dengan perbedaan implementasi tugas dan kewenangan Notaris antara yang ideal seperti UUJN 2014 dengan praktik di lapangan, yaitu: (a)Pemerintah melakukan revisi UUJN 2014 atau membuat Peraturan Pengganti Undang Undang.
\end{abstract}

Kata Kunci : Notaris, Akta Pertanahan.

\section{ABSTRACT}

The duties and authorities of Notary in making deed related to land shall be understood differently so as not to cause confusion. Questions arising from this problem are: How is the implementation of the task and authority of Notary in making deed related to land? What are the weaknesses in the implementation of the duties and authorities of Notary in making the deed related to land? How is the implementation solution of duties and authority of Notary in the making of Deed that is in assembly with land?

The approach method uses socio legal. The data used are primary and secondary data. Methods of data collection using interviews and literature study. Methods of data analysis using qualitative analysis.

Problems in the analysis with the theory of legal certainty and theories of authority: First, the implementation of duties and authorities of Notaries in making deed related to land is understood differently, because; (1) Referring to Article 15 paragraph (2) letter (f) of UUJN 2014, the Notary is automatically authorized to make the land deed. However, the facts in the field, Notary can not automatically become Land Acquisition Official (PPAT). (2) In practice in the field, Notary can be appointed to PPAT after attending the education and training and graduated from BPN. However, in the case that a Notary public makes deed - deed related to land which is not an obligation of PPAT. Second, the weakness of the implementation of duty and authority of Notary in making deed related to land are: (a) Ideal concept of implementation of duty and authority of Notary pursuant to UUJN 2014 that is a Notary as well as PPAT; (2) Practice of duties implementation and authority of Notary in the field is different from UUJN 2014, since Notary is appointed to PPAT after having to attend education and training and passed the event held by BPN; and Third solutions related to differences in the implementation of duties and authorities of Notary between the ideal such as UUJN 2014 with practice in the field, namely: (a) The Government revised the UUJN 2014 or made a Law Enforcement Rules.

Keywords: Notary, Land deed. 


\section{PENDAHULUAN}

Pada Pasal 33 ayat (3) Undang-Undang Dasar Negara Republik Indonesia Tahun 1945 dijelaskan bahwa bumi dan air dan kekayaan alam yang terkandung di dalamnya dikuasai oleh negara dan dipergunakan untuk sebesar-besarnya kemakmuran rakyat.Tugas negara untuk melindungi hak-hak rakyat atas tanah dan memberikan akses yang adil atas sumber daya agraria, termasuk tanah. Untuk itu, kebijakan pertanahan didasarkan kepada upaya konsisten untuk menjalankan amanat Pasal 33 ayat (3) UUDRI Tahun 1945 tersebut.

Kewenangan Negara dalam bidang pertanahan sebagaimana diatur dalam Pasal 2 ayat (2) UUPA, yakni :

(a) Mengatur dan menyelenggarakan peruntukan, penggunaan, persediaan dan pemeliharaan bumi, air dan ruang angkasa;

(b) Menentukan dan mengatur hubungan-hubungan hukum antara orang dengan bumi, air dan ruang angkasa;

(c) Menentukan dan mengatur hubungan-hubungan hukum antara orang dengan perbuatanperbuatan hukum yang mengenai bumi, air dan ruang angkasa.

Bidang pertanahan selama ini menjadi wewenang Badan Pertanahan Nasional (BPN) sesuai dengan Peraturan Presiden RI Nomor 10 Tahun 2006 tentang Badan Pertanahan Nasional dalam Pasal (2) disebutkan Badan Pertanahan Nasional melaksanakan tugas pemerintah di bidang pertanahan secara nasional, regional dan sektoral. Kemudian dalam Pasal (3) huruf $\mathrm{f}$, pelaksanaan pendaftaran tanah dalam rangka menjamin kepastian hukum; dan dalam huruf $\mathrm{g}$, pengaturan dan penetapan hak-hak atas tanah. Sesuai dengan ketentuan dalam Peraturan Pemerintah Nomor 37 Tahun 1998 wewenang dan tugas dalam masalah pertanahan ditugaskan kepada Pejabat Pembuat Akta Tanah (PPAT).

Lahirnya Undang-Undang Jabatan Notaris (UUJN) Nomor 30 Tahun 2004 yang kemudian diperbaharui dengan UUJN Nomor 2 Tahun 2014, memberi kesempatan bagi seorang Notaris untuk memiliki kewenangan membuat akta di bidang pertanahan, karena dalam UUJN No. 2Tahun 2014 Pasal (15), ayat 2berbunyi:

(1) Notaris berwenang membuat Akta autentik mengenai semua perbuatan, perjanjian, dan penetapan yang diharuskan oleh peraturan perundang-undangan dan/atau yang dikehendaki oleh yang berkepentingan untuk dinyatakan dalam Akta autentik, menjamin kepastian tanggal pembuatan Akta, menyimpan Akta, memberikan grosse, salinan dan kutipan
Akta, semuanya itu sepanjang pembuatan Akta itu tidak juga ditugaskan atau dikecualikan kepada pejabat lain atau orang lainyang ditetapkan oleh undang-undang.

(2) Selain kewenangan sebagaimana dimaksud pada ayat (1), Notaris berwenang pula:

a. mengesahkan tanda tangan dan menetapkan kepastian tanggal surat di bawah tangandengan mendaftar dalam buku khusus;

b. membukukan surat di bawah tangan dengan mendaftar dalam buku khusus;

c. membuat kopi dari asli surat di bawah tangan berupa salinan yang memuat uraian sebagaimana ditulis dan digambarkan dalam surat yang bersangkutan;

d. melakukan pengesahan kecocokan fotokopi dengan surat aslinya;

e. memberikan penyuluhan hukum sehubungan dengan pembuatan Akta;

f. membuat Akta yang berkaitan dengan pertanahan; atau

g. membuat Akta risalah lelang.

(3) Selain kewenangan sebagaimana dimaksud pada ayat (1) dan ayat (2), Notaris mempunyai kewenangan lain yang diatur dalam peraturan perundang-undangan.

Disebutkan bahwa Notaris dapat membuat akta yang berkaitan dengan pertanahan. Kemudian disebutkan dalam Pasal (15) ayat 1 Notaris berwenang membuat akta autentik mengenai semua perbuatan, perjanjian dan ketetapan yang diharuskan oleh peraturan perundang-undangan dan/ atau yang dikehendaki oleh yang berkepentingan untuk dinyatakan dalam akta autentikmenjamin kepastian tanggal pembuatan akta, menyimpan akta,memberikan grosse, salinan dan kutipan akta, semuanya itu sepanjang pembuatan akta-akta itu tidak juga ditugaskan atau dikecualikankepada pejabat lain atau orang lain yang ditetapkan oleh undang-undang.

Pada akhirnya Undang-Undang Jabatan Notaris menimbulkan pro dan kontra khususnya pada ketentuan yang berkaitan dengan pertanahan yang juga mengakibatkan banyak tafsir yang berbedabeda. Lahirnya UUJN Nomor 2Tahun 2014 khususnya Pasal (15) huruf $f$, telah memberi kontribusi lebih bagi seorang Notaris untuk ambil peran di bidang pertanahan secara menyeluruh. Selama ini pembuatan akta yang berkaitan dengan pertanahan menjadi wewenang Pejabat Pembuat Akta Tanah (PPAT), akan bergeser kepada fungsi penuh seorang Notaris yang sebelumnya hanya pada pembuatan akta autentik mengenai aspek keperdataan di luar bidang pertanahan. 
Pejabat Pembuat Akta Tanah diangkat oleh Menteri yang bertanggung jawab di bidang agraria/ pertanahan, kemudian diatur bahwa salah satu syarat untuk dapat diangkatsebagai PPAT adalah setelah lulus ujian yang diadakan oleh Kantor Menteri Agraria/ BPN. Dalam pelaksanaannya masih banyakmasyarakat belum mengetahui dan memahami secara seksama perbedaan antara Notaris dan PPAT. Seringkali ditemukan adanya perbedaan pemahaman antara jabatan Notaris dan PPAT. Padahal seperti diketahui keduanya merupakan 2 (dua) jabatan yang berbeda tugas dan kewenangannya.

Para Notaris tidak secara otomatis merangkap jabatan sebagai PPAT karena untuk menjadi PPAT ada syaratnya antara lain melalui ujian PPAT yang diselenggarakan oleh Badan Pertanahan Nasional, dan mengajukan penempatan kepada Kepala Badan Pertanahan Nasional, serta mengangkat sumpah jabatan PPAT dihadapan pejabat Badan Pertanahan Nasional.

Ketentuan dalam Pasal 15 ayat (2) huruf $f$ Undang-Undang Jabatan Notaris Nomor 2Tahun 2014 yang menyebutkan bahwa Notaris berwenang pula membuat akta yang berkaitan dengan pertanahan masih menimbulkan pro dan kontra. Lingkup kewenangan Notaris dalam Pasal 15 ayat(2) huruf $f$ tersebut tidak diatur dengan jelas mengenai jenisakta apa saja di bidang pertanahan yang menjadikewenangannya. Dalam UUJN Nomor 2 Tahun 2014 tidak ada ketentuan yang mengatur bahwa Notaris secara otomatis dapat menjadi Pejabat Pembuat Akta Tanah (PPAT), karena untuk menjadi PPAT ada persyaratan seperti telah disebutkan dalam Pasal 6 Peraturan Pemerintah Nomor 37Tahun 1998 tentang Pejabat Pembuat Akta Tanah (PPAT), yaitu telah mendapat pendidikan khusus spesialis notariatatau program pendidikan khusus PPAT yang diadakan oleh lembaga pendidikan tinggi di samping harus pula lulus dariujian yang diadakan oleh Kantor Menteri Negara Agraria/Kantor Pertanahan Nasional. Diangkat sebagai PPAT tanpa ujian ataupun yang belum pernahmendapatkan pendidikan khusus tentang PPAT tidak akan mungkin, namun ada PPAT sementara Camat atau Kepala Desa, maka tentunya pemerintah perlu mengatur dengan suatuPeraturan Menteri atas dispensasi tersebut.

Dalam melaksanakan tugas-tugas keagrarian atau yang berhubungan dengan pertanahan sebagaimana diatur dalam Peraturan Pemerintah RI No. 24 Tahun 1997, kedudukan PPAT sangat penting terutama sebagai pejabat umum yang berperan dalam hal bertugas melaksanakan sebagian kegiatan pendaftaran tanah dengan membuat akta sebagai bukti telah dilakukannya perbuatan hukum tertentu mengenai hak atas tanah karena setiap perjanjian yangbermaksud memindahkan atau mengalihkan hak atas tanah, menggadaikan tanah atau meminjam uang dengan hak atas tanah sebagai tanggungan harus dibuktikan dengan akta yang dibuat oleh dan di hadapan PPAT.

Berdasarkan uraian di atas, selama ini ada kerancuan dalam memahami tentang tugas dan kewenangan Notaris, PPAT, sehingga berpendapat bahwa Notaris secara otomatis adalah PPATpenulis bermaksud melakukan penelitian dengan fokus kajian tentang "Implementasi Tugas Dan Kewenangan Notaris Dalam Membuat Akta Yang Berkaitan Dengan Pertanahan".

\section{Metode Penelitian}

Penelitian merupakan suatu kegiatan ilmiah guna menemukan, mengembangkan ataupun menguji suatu pengetahuan yang dilakukan secara metodologis dan sistematis. Metode penelitian adalah cara kerja yang digunakan untuk dapat memahami obyek yang menjadi sasaran penelitian maupun ilmu yang bersangkutan untuk menemukan, mengembangkan dan menguji kebenaran suatu penelitian dan pengetahuan. ${ }^{1}$ Menurut Soetandyo Wignyosoebroto, penelitian hukum adalah seluruh upaya untuk mencari dan menemukan jawaban yang benar (right answer) dan/atau jawaban yang tidak sekali-kali keliru (true answer) mengenai suatu permasalahan. Untuk menjawab segala macam permasalahan hokum diperlukan hasil penelitian yang cermat, berketerandalan, dan sahih untuk menjelaskan dan menjawan permasalahan yang ada. ${ }^{2}$ Peter Mahmud Marzuki menambahkan tujuan dari penelitian hukum sesungguhnya merupakan proses untuk menemukan aturan hukum, prinsipprinsip hukum, maupun doktrin-doktrin hukum, guna menjawab isu hukum yang dihadapi. Dengan demikian, diharapkan dengan menggunakan metode dan pendekatan dalam penulisan ini, tinjauan terhadap implementasi tugas dan kewenangan Notaris dalam membuat akta yang berkaitan dengan pertanahan.

Pendekatan yang digunakan dalam penulisan tesis ini adalah socio-legal research ${ }^{3}$.Menurut

\footnotetext{
${ }^{1}$ Soerjono Soekanto.1986. Pengantar Penelitian Hukum, UI Press, Jakarta. HIm 15

${ }^{2}$ Zainuddin Ali.2012. Metode Penelitian Hukum, Sinar Grafika, Jakarta. HIm 18

${ }^{3}$ Sulistyowati Irianto, 2009, "Memperkenalkan Studi Sosiolegal dan Implikasi Metodologisnya", Metode
} 
Soemitro, socio-legal research atau yuridis sosiologis adalah meneliti dan mempelajari hukum sebagai studi law in action karena mempelajari dan meneliti hubungan timbal balik antara hukum dan lembagalembaga sosial yang lain studi hukum law in action merupakan studi sosial non doctrinal dan bersifat empiris. ${ }^{4}$ Penelitian ini juga memanfaatkan kepustakaan atau studi dokumen, karena penelitian ini banyak menganalisis melalui studi kepustakaan atau lebih dikenal dengan studi pada data sekunder. ${ }^{5}$

Socio-legal research merupakan penelitian yang mengkaji penerapan kaidah-kaidah atau norma-norma hukum yang berlaku di masyarakat. Pada penelitian ini kaidah atau norma yang terkait dengan implementasi tugas dan kewenangan Notaris dalam membuat akta yang berkaitan dengan pertanahan.

Spesifikasi penelitian ini menggunakan deskriptif analitis dikuatkan dengan perspektif, yaitu suatu penelitian yang menggambarkan secara menyeluruh dan sistematis obyek dari pokok permasalahan, dan berusaha memberikan gambaran mengenai masalah hukum, sistem hukum dan mengkajinya atau menganalisisnya sesuai dengan fakta yang ada dalam penelitian ini.

Peneliti menyusun data yang telah terkumpul, menganalisis serta untuk dapat diambil kesimpulannya serta memberikan suatu konsep tentang implementasi tugas dan kewenangan Notaris dalam membuat akta yang berkaitan dengan pertanahan.

Sumber data penelitian yang digunakan adalah data primer dan data sekunder. Data primer diperoleh dengan dari nara sumber yang dapat memberikan keterangan atau data yang terkait dengan fokus penelitian ini. Nara sumber penelitian ini adalah: Pimpinan atau Pegawai BPN Kabupaten Kendal; Notaris di Kabupaten Kendal.

Data sekunder diperoleh dengan cara memanfaatkan data-data yang telah ada yang terkait dengan judul penelitian. Data Sumber data dalam penelitian ini adalah bersumber dari bahan hukum primer dan bahan hukum sekunder.

Bahan hukum primer, berupa peraturan perundang-undangan yang mempunyai kekuatan hukum mengikat dan dapat dijadikan sebagai acuan dan pertimbangan hukum yang berguna dalam memahami fokus penelitian. Bahan hukum primer ini

Penelitian Hukum-Konstelasi dan Refleksi, ed. Sulistyowati Irianto dan Shidarta, Jakarta. HIm 175-177

${ }^{4}$ Ronny Hanitijo Soemitro, 1988, Metode Penelitian Hukum, Jakarta: Ghalia Indonesia. HIm 34

${ }^{5}$ Soerjono Soekanto dan Sri Mamudji, 2006, Penelitian Hukum Normatif, Suatu Tinjauan Singkat, Raja Grafindo Persada, Jakarta. HIm 13-14 terdiri dari : Undang - Undang Dasar Negara Republik Indonesia Tahun 1945, Kitab Undang Undang Hukum Perdata, Undang-Undang Nomor 2 Tahun 2014 tentang Perubahan Atas UndangUndang Nomor 30 Tahun 2004 tentang Jabatan Notaris, Peraturan Pemerintah Nomor 37 Tahun 1998 tentang Peraturan Jabatan Pejabatan Pembuat Akta Tanah, Peraturan Pemerintah RINomor 10 Tahun 2006 tentang Badan Pertanahan Nasional.

Bahan hukum sekunder yang dijadikan objek kajian dalam penelitian ini adalah bahan hukum yang memberikan penjelasan terhadap bahan hukum primer, seperti kamus hukum, ensiklopedia, kamus Bahasa Indonesia, buku-buku (literature) hukum yang ditulis oleh para ahli hukum yang berpengaruh, jurnal-jurnal hukum, pendapat para sarjana, serta makalah seminar-seminar oleh para pakar terkait dengan pembahasan.

Bahan hukum tersier adalah bahan-bahan yang memberikan informasi tentang bahan hukum primer dan bahan hukum sekunder, yang terdiri dari: Kamus Hukum; Kamus-kamus bidang studi lainnya yang terkait penelitian ini; Ensiklopedi.

Teknik untuk mengumpulkan data digunakan metode studi kepustakaan, observasi, dan wawancara. Metode ini digunakan untuk mengumpulkan data sekunder.Studi kepustakaan adalah kegiatan mengumpulkan dan memeriksa atau menelusuri dokumen-dokumen atau kepustakaan yang dapat memberikan informasi atau keterangan yang dibutuhkan oleh peneliti. Studi pustaka dalam penelitian hukum bertujuan untuk menemukan bahan-bahan hukum, baik yang bersifat primer, sekunder maupun tersier. Bahan-bahan hukum tersebut dijadikan patokan atau norma dalam menilai fakta-fakta hukum yang akan dipecahkan sebagai masalah hukum.

Bahan-bahan hukum tersebut merupakan data sekunder, yaitu data yang didapatkan secara tidak langsung dari nara sumber tetapi data yang telah tersedia dan dijadikan informasi bagi yang membutuhkan, baik berbentuk peraturan, buku, laporan, jurnal, dan sejenisnya.

Menurut Sugiyono menjelaskan bahwa, "Teknik pengumpulan data dengan observasi digunakan bila, penelitian berkenaan dengan prilaku manusia, proses kerja, gejala-gejala alam dan bilar esponden yang diamati tidak terlalu besar." Observasi diartikan sebagai pengamatan dan pencatatan secara sisitematik terhadap suatu gejala yang tampak pada objek penelitian.

Studi lapangan ini digunakan untuk mendapatkan data primer yaitu data yang langsung didapatkan dari sumber pertama yang dijadikan nara sumber penelitian ini melalui wawancara. Wawancara 
digunakansebagai teknik pengumpulan data apabila peneliti ingin melakukan studipendahuluan untuk menemukan permasalahan yang harus diteliti, danjuga apabila peneliti ingin mengetahui hal-hal dari responden yang lebihmendalam dan jumlah responden sedikit atau kecil."

Cara wawancara dalam penelitian ini menggunakan bebas terpimpin.Wawancara jenis ini merupakan kombinasi dari wawancara tidak terpimpin dan wawancara terpimpin. Meskipun terdapat unsur kebebasan, tetapi ada pengaruh pembicaraan secara tegas dan mengarah. jadi wawancara jenis ini mempunyai ciri fleksibilitas (keluwesan) dan arah yang jelas.

Pengambilan sampel dalam penelitian ini dengan cara Purposive Sample. Purposive sampling ${ }^{6}$ maksudnya adalah menentukan sampel dengan berbagai pertimbangan atau alasan.Teknik ini digunakan untuk menentukan sampel pejabat umum berdasarkan kewenangannya. Menurut Sugiyono purposive sampling adalah teknik pengambilan sampel sumber data dengan pertimbangan tertentu. Pertimbangan tertentu ini, misalnya orang tersebut yang dianggap paling tahu tentang apa yang kita harapkan, atau mungkin dia sebagai penguasa sehingga akan memudahkan peneliti menjelajahi obyek atau situasi sosial yang diteliti.

Teknik analisis data yang digunakan dalam penelitian ini adalah deskriptif kualitatif, yaitu data yang diperoleh dari hasil penelitian lapangan dan penelitian kepustakaan disusun secara sistematis, kemudian dilakukan analisis secara deskriptif kualitatif, dengan memperhatikan fakta-fakta yang ada dalam praktik, kemudian dibandingkan dengan data-data yang diperoleh dari penelitian kepustakaan, sehingga dapat diperoleh jawaban dan kesimpulan tentang permasalahan yang telah dirumuskan.

Analisis deskriptif adalah kegiatan pengkajian hasil olah data yang hanya sampai pada taraf deskripsi, yaitu menyajikan dan menafsirkan faktafakta secara sistematik sehingga dapat lebih mudah dipahami dan disimpulkan.Pada analisis ini kesimpulan yang diberikan selalu jelas dasar faktualnya sehingga semuanya selalu dapat dikembalikan langsung pada data yang diperoleh.

Demi menjamin validitas data, maka teknik analisis data menggunakan triangulasi data. Menurut Sugiyono triangulasi data yaitu teknik pengumpulan data yang bersifat menggabungkan dari berbagai teknik pengumpulan data dan sumber data yang

\footnotetext{
${ }^{6}$ Sugiyono.2012. Metode Penelitian Kuantitatif, Kualitatif dan R\&D. Alfabeta. Bandung. HIm 218-219
}

telah ada. Bila peneliti melakukan pengumpulan data dengan triangulasi, maka sebenarnya peneliti mengumpulkan data yang sekaligus menguji kredibilitas data, yaitu mengecek kredibilitas data dengan berbagai teknik pengumpulan data dan berbagai sumber data. ${ }^{7}$

\section{HASIL DAN PEMBAHASAN}

\section{Implementasi Tugas dan Kewenangan Notaris dalam Membuat Akta yang Berkaitan dengan Pertanahan}

\section{Notaris danPPAT}

\section{a. Perbedaan Implementasi Notaris danPPAT}

Sesuai Pasal 15 ayat (2) UU Nomor 2 Tahun 2014 (UUJN 2014) huruf (f) dan (g) maka Notaris diberi berwenang pula membuat akta tanah. Hal ini dapat dicermati pada Pasal 15 ayat (2) UUJN 2014 yang menegaskan bahwa Notaris berwenang pula, yaitu membuat Akta yang berkaitan dengan pertanahan (huruf f). Berdasarkan ketentuan ini secara otomatis Notaris memiliki kewenangan membuat akta tanah. Mengacu pada UUJN 2014 ini, maka Notaris secara otomatis adalah pejabat yang berwenang membuat akta tanah dan risalah lelang. Namun kenyataan di lapangan, Notaris tidak secara otomatis dapat menjadi Pejabat Pembuat Akta Tanah (PPAT).

Notaris tidak dapat secara otomatis menjadi PPAT seperti UUJN 2014, karena untuk dapat diangkat menjadi PPAT seorang Notaris harus mengikuti pendidikan dan pelatihan serta lulus yang diselenggaran oleh BPN. Mengingat Notaris tidak secara otomatis sebagai PPAT, maka implementasi Pasal 15 ayat (2) huruf (f) UUJN 2014 di lapangan tidak dapat berjalan mulus karena berbenturan dengan Peraturan Kepala Badan Pertanahan NasionalNomor 23 Tahun 2009TentangPerubahan Atas Peraturan Kepala Badan Pertanahan NasionalNomor 1 Tahun 2006 Tentang KetentuanPelaksanaan Peraturan Pemerintah Nomor 37 Tahun 1998Tentang Peraturan JabatanPejabat Pembuat Akta Tanah.

Peraturan Kepala Badan Pertanahan NasionalNomor 23 Tahun 2009 Pasal 14 mengatur bahwa untuk dapat mengikuti ujian PPAT, yang bersangkutan berusia palingkurang 30 (tiga puluh) tahun dan wajib mendaftar pada panitiapelaksana ujian Badan Pertanahan Nasional Republik Indonesia denganmelengkapi persyaratan:

a. fotocopy KTP yang masih berlaku;

7 Sugiyono, Memahami Penelitian Kualitatif, Alfabeta, Bandung, 2010, HIm. 83. 
b. pas photo berwarna dengan ukuran $4 \times 6$ sebanyak 3 (tiga) lembar; dan

c. fotocopy ijazah S1 dan Program Pendidikan Khusus PPAT yangdiselenggarakan oleh lembaga pendidikan tinggi, atau ijazah ProgramPendidikan Spesialis Notariat atau Magister Kenotariatan yangdilegalisir oleh pejabat yang berwenang.

Persyaratan di atas ditambah lagi seperti tertera pada Pasal 15 Peraturan Kepala Badan Pertanahan NasionalNomor 23 Tahun 2009, yaitu:

(1) Calon PPAT yang telah lulus ujian PPAT sebagaimana dimaksud dalamPasal 11 ayat (2), mengajukan permohonan pengangkatan sebagai PPAT kepada Kepala Badan sesuai bentuk sebagaimana tercantumdalam Lampiran I.

(2) Permohonan pengangkatan sebagaimana PPAT, dilengkapi denganpersyaratan:

a. Surat Keterangan Catatan Kepolisian (SKCK) dan/atau surat keterangan yang pada intinya menerangkan tidak pernahmelakukan tindak pidana kejahatan yang dikeluarkan oleh InstansiKepolisian.

b. Surat keterangan kesehatan dari dokter umum atau dokter spesialis yang menyatakan bahwa yang bersangkutan sehat jasmani dan rohani;

c. Surat pernyataan bermeterai cukup dari yang bersangkutan yangmenyatakan bahwa yang bersangkutan sehat jasmani dan rohani;

d. Surat pernyataan bermeterai cukup dari yang bersangkutan yangmenyatakan tidak rangkap jabatan;

f. Daftar riwayat hidup; dan

g. Fotocopy ijazah S1 dan Program Pendidikan Khusus PPAT yangdiselenggarakan oleh lembaga pendidikan tinggi, atau ijazahProgram Pendidikan Spesialis Notariat atau Magister Kenotariatanyang dilegalisir oleh pejabat yang berwenang.

Berdasarkan kenyataan di atas, maka implementasi di lapangan seorang Notaris tidak dapat secara otomatis sebagai PPAT. Menanggapi hal ini Ady Kusnadi berpendapat bahwa kehadiran Undang-Undang Jabatan Notaris No. 30/2004 yang telah diperbarui dengan Undang-Undang Jabatan Notaris No. 2/2014bertentangan dengan tiga undang-undang di bidang pertanahan.Ketiga undang-undang yang ditabrak oleh UUJN yaitu UU No. 5/1960 tentang Pokok-Pokok Agraria, UU No. 16/1985 tentangRumah Susun, dan UU No. 4/1996 tentang Hak Tanggungan.Ketentuan UUJN yang bertentangan dengan tiga undang-undangdi bidang pertanahan adalah pasal 15 ayat (2) huruf $f$ yang mengaturkewenangan Notaris untuk membuat akta yang berkaitan denganpertanahan. ${ }^{8}$

\section{b. Kewenangan Notaris dan PPAT}

Terkait denganimplementasi Pasal 15 huruf (f) UUJN 2014 bahwa Notaris tidak dapat secara otomatis sebagai PPAT, maka jabatan Notaris, PPAT harus dipahami, karena masing-masing memiliki tugas pokok, fungsi dan kewenangan yang berbeda. Menurut Junaidi ${ }^{9}$, dijelaskan bahwa Notaris pada dasarnya pejabat yang berwenang membuat akta. Namun untuk memiliki kewenangan membuat akta tanah ia harus sudah diangkat menjadi PPAT. Notaris belum tentu sebagai PPAT, karena untuk dapat diangkat sebagai PPAT harus mengikuti pendidikan dan pelatihan tertentu untuk itu. Pendapat senada juga dikatakan oleh Sri Waryanti. ${ }^{10}$ yaitu: perlu dipahami bahwa jabatan Notaris, PPAT harus sangat dipahami. Artinya bahwa Notaris tidak secara otomatis menjadi PPAT. Namun setiap PPAT adalah Notaris. Perlu saya tegaskan kembali bahwa Notaris belum tentu sebagai PPAT. Untuk dapat menjadi PPAT, seorang Notaris harus mengikuti pendidikan dan pelatihan serta lulus ujian yang diselenggaran oleh BPN.

Pendapat di atas juga didukung oleh pendapat Wiwin Roswinanti ${ }^{11}$ yang mengatakan bahwa pada prinsipnya jabatan Notaris, PPATmemiliki tupoksi (tugas pokok dan fungsi) dan kewenangan yang berbeda. Notaris dapat diangkat sebagai PPAT. Notaris sebagai PPAT berwenang membuat akta tanah. PPAT adalah Notaris yang telah mengitkui pendidikan dan pelatihan serta dinyatakan lulus yang diselenggaran oleh BPN.

Berdasarkan hasil wawancara di atas, diketahui bahwa antara Notaris dan PPAT. Notaris tidak secara otomatis menjadi PPAT, namun untuk dapat diangkat sebagai PPAT seorang Notaris harus memiliki kompetensi yang dibutuhkan sesuai perundang-undangan yang berlaku. Jadi yang membedakan antara jabatan Notaris dan PPAT adalah karena tugas pokok, fungsi dan kewenangan yang dimiliki kedua jabatan tersebut adalah berbeda. Namun demikian, kedua jabatan tersebut memiliki kesamaan yaitu Notaris dan PPAT sama-sama memiliki kewenangan untuk membuat akta otentik.

Dengan adanya perbedaan kedudukan antara Notaris dan PPATtersebut tidak menimbulkan

\footnotetext{
${ }^{8}$ Ady Kusnadi, dkk, Op.cit,Hlm.50.

${ }^{9}$ Wawancara dengan Junaidi, sebagaiNotaris di Kabupaten Kendaltanggal 25 Januari 2016.

${ }^{10}$ Wawancara dengan Sri Waryanti.Mkn sebagai Notaris di Kabupaten Kendal, tanggal 26 Januari 2016.

${ }^{11}$ Wawancara dengan Wiwin Roswinanti sebagai Notaris di Kabupaten Kendal, tanggal 27 Januari 2018.
} 
kerancuan atau tumpang tindih? Menurut Junaidi ${ }^{12}$, dijelaskan hal tersebut tidak rancu, karena jabatan Notaris dan PPAT pada dasarnya memiliki kewenangan yang berbeda. Jadi Notaris tidak secara otomatis menjadi PPAT. Untuk menjadi PPAT salah satu syaratnya adalah yang bersangkutan adalah Notaris. Pendapat senada juga dikatakan oleh Sri Waryanti. ${ }^{13}$ Bahwa hal itu tidak rancu, justru hal ini dapat menjadi daya pembeda antara Notaris yang biasa dengan Notaris yang telah memiliki kompetensi yang lebih. Setiap jabatan pasti menuntut profesionalisme, maka adanya ketentuan tentang persyaratan bagi Notaris untuk dapat diangkat sebagai PPAT dapat mendorong Notaris untuk meningkatkan profesionalismenya.

Pendapat di atas juga didukung oleh pendapat Wiwin Roswinanti ${ }^{14}$ yang mengatakan bahwa hal tersebut tidak akan rancu, karena masingmasing jabatan Notaris, PPAT sudah diatur dengan perundangan sendri-sendiri. Notaris diatur melalui UUJN No. 2 Tahun 2014 tentang Jabatan Notaris, PPAT diatur melalui PP Nomor 37 Tahun 1998TentangPeraturan Jabatan Pejabat Pembuat Akta Tanah (PPAT).

Berdasarkan wawancara di atas diketahui bahwa dengan adanya kedudukan yang berbeda antara Notaris, PPAT tidak akan menimbulkan kerancuan, justru hal ini semakin memperjelas perbedaan tugas pokok, fungsi dan kewenangan masing-masing jabatan tersebut, sehingga dapat mempertegas pemahaman tentang Notaris, PPAT dan Pejabat lelang Kelas II.

\section{Perbedaan Notaris dan PPAT}

Notaris dan PPAT memilki perbedaan dilihat dari tugas pokok, fungsi dan kewenangan termasuk juga dilihat dari persyaratan untuk dapat diangkat pada jabatan tersebut. Menurut penuturan Junaidi ${ }^{15}$, dijelaskan bahwa Notaris memiliki kedudukan yang berbeda dengan PPAT, karena Notaris yang belum diangkat menjadi PPAT tidak berwenang membuat akta tanah. Pendapat senada juga dilontarkan oleh Sri Waryanti. ${ }^{16}$ bahwa jabatan Notaris tidak identik dengan PPAT, karena sebelum diangkat menjadi PPAT seorang Notaris belum memiliki kewenangan

\footnotetext{
${ }^{12}$ Wawancara dengan Junaidi sebagaiNotaris di Kabupaten Kendal , tanggal 25 Januari 2018.

${ }^{13}$ Wawancara dengan Sri Waryanti sebagaiNotaris Kabupaten Kendal, tanggal 26 Januari 2018.

${ }^{14}$ Wawancara dengan Wiwin Roswinanti sebagaiNotaris Kabupaten Kendal, tanggal 27 Januari 2018.

${ }^{15}$ Wawancara dengan Junaidi, sebagaiNotaris di Kabupaten Kendal tanggal 25 Januari 2018.

${ }^{16}$ Wawancara dengan Sri Waryanti.Mkn sebagaiNotaris di Kabupaten Kendal, tanggal 26 Januari 2018.
}

membuat akta tanah. Pendapat tersebut juga dibenarkan oleh Wiwin Roswinanti ${ }^{17}$ yang mengatakan bahwa Notaris biasa tidak berhak membuat akta tanah, Tidak, karena yang berhak membuat akta tanah adalah PPAT. Maka sebelum diangkat sebagai PPAT, Notaris belum memiliki kewenangan membuat akta tanah.

Berdasarkan hasil wawancara di atas diketahui bahwa Notaris yang belum diangkat sebagai PPAT tidak memiliki kewennagan untuk membuat akta tanah. Pejabat Pembuat Akta Tanah (PPAT) adalah Pejabat Umum yang kewenangannya diatur dalam Undang-Undang Pokok Agraria dan Peraturan Pemerintah Nomor 10/1961 juncto Peraturan Pemerintah Nomor 24/1997 juncto Peraturan Pemerintah Nomor 37 Tahun 1998 tentang Peraturan Jabatan Pejabat Pembuat Akta Tanah (PP 37/1998). Sebagai Pejabat pembuat Akta Tanah maka segala hal yang berkenaan dengan akta-akta peralihan hak atas tanah, pemberian hak baru atas tanah dan pengikatan tanah sebagai jaminan hutang, merupakan tugas dan tanggung jawab Pejabat Pembuat Akta Tanah (PPAT) serta harus dibuat dihadapannya.

\section{a. Syarat Pengangkatan PPAT}

Seorang Notaris dapat diangkat menjadi PPAT setelah yang bersangkutan mengikuti pendidikan dan pelatihan serta dinyatakan lulus yang diselenggaraka oleh BPN. Hal ini seperti yang dikatakan oleh Junaidi ${ }^{18}$ yang menjelaskan bahwa untuk dapat diangkat sebagai PPAT, maka Notaris harus mengikuti pelatihan dan lulus ujian yang diselenggarakan oleh Kantor Menteri Negara Agraria/Badan PertanahanNasional.Sri Waryanti. ${ }^{19}$ juga mengatakan bahwa untuk dapat diangkat menjadi PPAT, seorang Notaris harus mengikuti pelatihan dan pelatihan serta dinyatakan lulus ujian yang diselenggarakan oleh Kantor Menteri Negara Agraria melalui BPN. Hal ini juga dikatakan oleh Wiwin Roswinanti ${ }^{20}$ yang mengatakan bahwa untuk menjadi PPAT, seorang Notaris harus mengikuti pendidikan dan pelatihan yang diselenggarakan oleh BPN.

\section{b. Syarat Pengangkatan PPAT}

\footnotetext{
${ }^{17}$ Wawancara dengan Wiwin Roswinanti sebagaiNotaris Kabupaten Kendal, tanggal 27 Januari 2018.

${ }^{18}$ Wawancara dengan Junaidi sebagaiNotaris di Kabupaten Kendal, tanggal 25 Januari 2018.

${ }^{19}$ Wawancara dengan Sri Waryanti.Mkn, sebagai Notaris di Kabupaten Kendal, tanggal 26 Januari 2018.

${ }^{20}$ Wawancara dengan Wiwin Roswinanti, sebagai Notaris di Kabupaten Kendal, tanggal 27 Januari 2018.
} 
Peraturan Kepala Badan Pertanahan Nasional Nomor 23 Tahun 2009TentangPerubahan Atas Peraturan Kepala Badan Pertanahan Nasional Republik Indonesia Nomor 1 Tahun 2006 Tentang KetentuanPelaksanaan Peraturan Pemerintah Nomor 37 Tahun 1998Tentang Peraturan JabatanPejabat Pembuat Akta Tanah Pasal 12 ayat (3) berbunyi bahwa materi ujian PPAT terdiri dari:

1) Hukum Pertanahan Nasional;

2) Organisasi dan Kelembagaan Pertanahan;

3) Pendaftaran Tanah;

4) Peraturan Jabatan PPAT;

5) Pembuatan Akta PPAT; dan

6) Etika profesi.

Peraturan Kepala Badan Pertanahan NasionalNomor 23 Tahun 2009Pasal 14 menjelaskan bahwa untuk dapat mengikuti ujian PPAT, yang bersangkutan berusia palingkurang 30 (tiga puluh) tahun dan wajib mendaftar pada panitiapelaksana ujian Badan Pertanahan Nasional Republik Indonesia denganmelengkapi persyaratan:

1) fotocopy KTP yang masih berlaku;

2) pas photo berwarna dengan ukuran $4 \times 6$ sebanyak 3 (tiga) lembar; dan

3) fotocopy ijazah S1 dan Program Pendidikan Khusus PPAT yangdiselenggarakan oleh lembaga pendidikan tinggi, atau ijazah ProgramPendidikan Spesialis Notariat atau Magister Kenotariatan yangdilegalisir oleh pejabat yang berwenang.

Peraturan Kepala Badan Pertanahan NasionalNomor 23 Tahun 2009Pasal 15 Ayat (2) dijelaskan bahwa permohonan pengangkatan sebagaimana PPAT, dilengkapi denganpersyaratan:

1) Surat Keterangan Catatan Kepolisian (SKCK) dan/atau suratketerangan yang pada intinya menerangkan tidak pernahmelakukan tindak pidana kejahatan yang dikeluarkan oleh InstansiKepolisian.

2) Surat keterangan kesehatan dari dokter umum atau dokterspesialis yang menyatakan bahwa yang bersangkutan sehatjasmani dan rohani;

3) Surat pernyataan bermeterai cukup dari yang bersangkutan yangmenyatakan bahwa yang bersangkutan sehat jasmani dan rohani;

4) Surat pernyataan bermeterai cukup dari yang bersangkutan yangmenyatakan tidak rangkap jabatan;

5) Daftar riwayat hidup; dan

6) Fotocopy ijazah S1 dan Program Pendidikan Khusus PPAT yangdiselenggarakan oleh lembaga pendidikan tinggi, atau ijazahProgram Pendidikan Spesialis Notariat atau Magister Kenotariatanyang dilegalisir oleh pejabat yang berwenang.

\section{c. Wilayah Kerja PPAT}

Seorang notaris biasanya merangkap jabatan sebagai PPAT, hal ini terjadi karena adanya sinergi atau hubungan antara keduanya.PPAT sudah dikenal sejak berlakunya Peraturan Pemerintah Nomor 10 Tahun 1961 tentang Pendaftaran Tanah, PP ini merupakan delegasi dari pasal 19 Undang-undang Nomor 5 Tahun 1960 Tentang Peraturan Pokok Agraria (UUPA) yang memerintahkan kepada Pemerintah untuk melaksanakan pendaftaran tanah. ${ }^{21}$

Dalam Undang-undang Nomor 4 Tahun 1996 Tentang Hak Tanggungan atas Tanah Beserta Benda-benda Yang Berkaitan Dengan Tanah dan Peraturan Pemerintah Nomor 24 Tahun 1997 Tentang Pendaftaran Tanah sebagai pengganti dari PP No. 10 Tahun 1961, fungsi PPAT yaitu sebagai pejabat umum yang berwenang membuat akta pemindahan hak atas tanah, pembebanan hak atas tanah, dan akta-akta lain yang diatur dengan peraturan perundang-undangan yang berlaku dan membantu Kepala Kantor Pertanahan dalam melaksanakan pendaftaran tanah dengan membuat akta-akta yang akan dijadikan dasar pendaftaran perubahan data pendaftaran tanah. ${ }^{22}$

Dalam Peraturan Pemerintah Republik Indonesia Nomor 37 Tahun 1998 Tentang Peraturan Jabatan Pejabat Pembuat Akta Tanah pasal 2 ayat (1) fungsi PPAT lebih ditegaskan lagi bahwa PPAT bertugas pokok melaksanakan sebagian kegiatan pendaftaran tanah dengan membuat akta sebagai bukti telah dilakukannya perbuatan hukum tertentu mengenai hak atas tanah atau Hak Milik Atas Satuan Rumah Susun, yang akan dijadikan dasar bagi pendaftaran perubahan data pendaftaran tanah yang diakibatkan oleh perbuatan hokum itu.

Pengangkatan dan pemberhentian PPAT ditentukan oleh Menteri Negara Agraria/Kepala Badan Pertanahan Nasional sesuai Pasal 5 dan 8 Peraturan Pemerintah Republik Indonesia Nomor 37 Tahun 1998 Tentang Peraturan Jabatan Pejabat Pembuat Akta Tanah. Sebagai pejabat yang melaksanakan tugas dibidang pendaftaran tanah maka jabatan PPAT selalu dikaitkan dengan suatu wilayah pendaftaran tanah tertentu yang menjadi daerah kerjanya. ${ }^{23}$

Dalam pelaksanaan wewenang, jika misalnya ada seorang pejabat yang melakukan suatu tindakan diluar atau melampaui kewenangannya melakukan

21 H. Ali Achmad Chomzah. 2004. Hukum Agraria (Pertanahn Indonesia) Jilid 2, Prestasi Pustaka, Jakarta.HIm. 95.

22 Boedi Harsono. 2002.Hukum Agraria Indonesia, Himpunan Peraturan-peraturan Hukum Tanah, Djambatan, Jakarta.HIm. 689.

${ }^{23}$ Ibid, HIm. 691. 
pelanggaran terhadap kewajiban dan larangan jabatan, maka perbuatannya itu akan dianggap sebagai perbuatan melanggar hukum. Demikian pula dengan notaris dan PPAT, para notaris dan PPAT wajib untuk mengetahui batas kewenangannya. Selain wewenang yang mereka miliki, notaris juga memilki kewajiban yang harus mereka penuhi dalam pelaksanaan tugas jabatannya serta larangan yang tidak boleh dilakukan yang apabila ketiga hal ini dilanggar maka Notaris dan PPAT yang bersangkutan akan memperoleh sanksi sesuai dengan ketentuan yang telah diatur dalam Undang-undang Jabatan Notaris (UUJN) maupun Peraturan Pemerintah Republik Indonesia Nomor 37 Tahun 1998 Tentang Peraturan Jabatan PPAT.

Notaris dan PPAT mengemban tugas sebagai pejabat umum yang membuat akta otentik, dalam mengemban tugasnya harus mematuhi ramburambu hukum yang sesuai dengan peraturan perundang-undangan, namun didalam peraturan perundang-undangan itu sendiri terdapat dissinkronisasi atau tidak selaras, dalam hal ini Pasal 17 huruf (g) Undang-Undang Nomor 2 Tahun 2014 Tentang Perubahan Undang-Undang Nomor 30 Tahun 2004 Tentang Jabatan Notaris (UUJN) dengan Pasal 8 ayat (1) huruf (c) Peraturan Pemerintah Nomor 37 tahun 1998 Tentang Peraturan Jabatan Pejabat Pembuat Akta Tanah, pasal-pasal yang terdapat dalam kedua peraturan perundangundangan tersebut mengatur tentang laranganlarangan bagi Notaris dan PPAT yang berkaitan mengenai tempat kedudukan dan wilayah jabatan notaris dan PPAT.Secara keseluruhan dalam pasal 17 UUJN mengatur tentang larangan-larangan bagi notaris, Didalam Pasal 17 huruf $(\mathrm{g})$ dijelaskan bahwa notaris dilarang merangkap jabatan sebagai Pejabat Pembuat Akta Tanah di luar wilayah jabatan Notaris.Untuk dapat memahami apa yang dimaksud dengan wilayah jabatan maka dapat melihat substansi dari pasal 18 UUJN, sebagai berikut: a. Pasal 18 Ayat (1) menyebutkan bahwa:Notaris mempunyai tempat kedudukan didaerah kabupaten atau kota, b. Pasal 18 ayat (2) menyebutkan bahwa: "Notaris mempunyai wilayah jabatan meliputi seluruh wilayah provinsi dari tempat kedudukannya".

Menurut pasal 18 ayat (2) notaris mempunyai wilayah jabatan meliputi seluruh wilayah propinsi dari tempat kedudukannya. Pengertian tempat kedudukan Notaris dan wilayah jabatan Notaris adalah notaris mempunyai wilayah kerja satu propinsi dari tempat kedudukannya, artinya Notaris dapat saja membuat akta di luar tempat kedudukannya selama sepanjang masih berada pada propinsi yang sama. ${ }^{24}$

Atas dasar uraian pasal 18 diatas maka dapat dibedakan pengertian tempat kedudukan dengan wilayah jabatan. Bahwa didalam pasal 17 huruf (g) UUJN bila dikaji lebih jauh dapat ditarik suatu kesimpulan bahwa pasal tersebut memungkinkan Notaris merangkap jabatan sebagai PPAT didalam wilayah jabatan Notaris tanpa memperhatikan tempat kedudukan notaris, sedangkan didalam Pasal 8 ayat (1) huruf (c) Peraturan Pemerintah Nomor 37 tahun 1998 Tentang Peraturan Jabatan Pejabat Pembuat Akta Tanah menyebutkan bahwa:

PPAT berhenti menjabat karena PPAT tersebut diangkat dan mengangkat sumpah jabatan atau melaksanakan tugas sebagai Notaris dengan tempat kedudukan di Kabupaten/Kotamadya Daerah Tingkat II yang lain daripada daerah kerjanya sebagai PPAT.

\section{Notaris Sebagai PPAT}

Menurut Undang-Undang Nomor 4 tahun 1996tentang Hak Tanggungan Atas Tanah Beserta Benda-Benda yangBerkaitan Dengan tanah. Yang disebut dengan PPAT adalah pejabatumum yang diberikan wewenang untuk membuat akta pemindahan hakatas tanah, akta pembebanan hak atas tanah dan akta pemberi kuasapembebanan hak Tanggungan menurut Peraturan Perundangundanganyang berlaku. Sedangkan menurut Peraturan Pemerintah Nomor 37 Tahun 1998 TentangPeraturan Jabatan Pejabat Pembuat Akta Tanah yang disebut PejabatPembuat Akta Tanah yang biasa disingkat PPAT adalah pejabat umumyang diberikan kewenangan membuat akta-akta otentik perbuatan hukumtertentu mengenai hak atas tanah atau hak milik atas satuan rumah susun.

Implementasi yang mandiri Notaris bisa laksanakan dalam membuat akta yang berkaitan dengan Akta Pertanahan yaitu :
a. Keterangan Hak Waris
b. Pengikatan Jual Beli
c. Kuasa Menjual
d. Perjanjian Sewa Menyewa
e. Perjanjian Kredit

Implementasi dalam bentuk bahwa Notaris sebagai PPAT yaitu membuat akta-akta PPAT, sehingga pada saat yang bersamaan adalah selaku Notaris, akan tetapi ketika menjalankan tugas tersebut adalah Notaris sebagai PPAT.

24 Habib Adjie. 2009. Hukum Notaris Indonesia, Refika Aditama, Bandung.HIm. 95. 


\section{Kelemahan Tugas dan Kewenangan Notaris dalam Membuat Akta yang Berkaitan dengan Pertanahan}

\section{Konsep Ideal Implementasi Tugas dan Kewenangan Notaris Menurut UUJN 2014}

Sesuai UUJN 2014, maka Notaris semestinya secara otomatis sebagai PPAT. Hal ini dapat dicermati seperti termuat pada Pasal 15 UUJN 2014 yang mengatur bahwa kewenangan Notaris adalah sebagai berikut ini.

(1) Notaris berwenang membuat Akta autentik mengenai semua perbuatan, perjanjian, dan penetapanyang diharuskan oleh peraturan perundang-undangan dan/atau yang dikehendaki oleh yangberkepentingan untuk dinyatakan dalam Akta autentik, menjamin kepastian tanggal pembuatanAkta, menyimpan Akta, memberikan grosse, salinan dan kutipan Akta, semuanya itu sepanjangpembuatan Akta itu tidak juga ditugaskan atau dikecualikan kepada pejabat lain atau orang lainyang ditetapkan oleh undang-undang.

(2) Selain kewenangan sebagaimana dimaksud pada ayat (1), Notaris berwenang pula:

a. mengesahkan tanda tangan dan menetapkan kepastian tanggal surat di bawah tangandengan mendaftar dalam buku khusus;

b. membukukan surat di bawah tangan dengan mendaftar dalam buku khusus;

c. membuat kopi dari asli surat di bawah tangan berupa salinan yang memuat uraiansebagaimana ditulis dan digambarkan dalam surat yang bersangkutan;

d. melakukan pengesahan kecocokan fotokopi dengan surat aslinya;

e. memberikan penyuluhan hukum sehubungan dengan pembuatan Akta;

f. membuat Akta yang berkaitan dengan pertanahan; atau

g. membuat Akta risalah lelang.

(3) Selain kewenangan sebagaimana dimaksud pada ayat (1) dan ayat (2), Notaris mempunyaikewenangan lain yang diatur dalam peraturan perundang-undangan."

Sesuai UUJN 2014 Pasal 15 ayat (2) huruf (f), maka secara ideal bahwa Notaris adalah pejabat pembuat akta tanah (PPAT). Hal ini karena pasalpasal UUJN 2014 selanjutnya tidak mengatur tentang ketentuan yang menegaskan bahwa untuk dapat diangkat menjadi PPAT, seorang Notaris harus mengikuti pendidikan dan pelatihan serta dinyatakan lulus oleh suatu lembaga atau departemen tertentu.

Mengingat kedudukan UUJN 2014 lebih tinggi dibandingkan dengan Peraturan Kepala Badan
Pertanahan Nasional Nomor 23 Tahun 2009Tentang Perubahan Atas Peraturan Kepala Badan Pertanahan Nasional Nomor 1 Tahun 2006 Tentang Ketentuan Pelaksanaan Peraturan Pemerintah Nomor 37 Tahun 1998Tentang Peraturan Jabatan Pejabat Pembuat Akta Tanah, maka kedua peraturan tersebut mestinya sudah tidak berlaku lagi, karena sifat kedua peraturan ini lebih merupakan petunjuk pelaksanaan atau petunjuk teknis dari UUJN 2014.

Menurut Undang-Undang Nomor 12 Tahun 2011 tentang Pembentukan Peraturan PerundangUndangan telah mengatur tentang Jenis dan Hierarki Peraturan Perundang-undangan yang terdiri atas:

a. Undang-Undang Dasar Negara Republik Indonesia Tahun 1945;

b. Ketetapan Majelis Permusyawaratan Rakyat;

c. Undang-Undang /Peraturan Pengganti UndangUndang;

d. Peraturan Pemerintah;

e. Peraturan Presiden;

f. Peraturan Daerah Provinsi; dan

g. Peraturan Daerah Kabupaten/Kota.

Mengacu UU No 12 tahun 2011 di atas, maka peraturan yang tidak sesuai atau bertentangan dengan peraturan di atasnya dinyatakan batal demi hukum. Terkait dengan UUJN 2014 yang telah mengatur bahwa Notaris berwenang pula membuat akta tanah (PPAT), maka peraturan BPN mestinya dinyatakan batal demi hukum dan tidak berlaku lagi, sehingga Notaris secara otomatis menjadi PPAT.

\section{Praktik Implementasi Tugas dan Kewenangan Notaris di Lapangan}

Saat ini praktik implementasi tugas dan kewenangan Notaris di lapangan masih sama seperti sebelum adanya UUJN 2014, karena Notaris tidak dapat secara otomatis sebagai PPAT. Pihak BPN masih berpedoman pada aturan yang telah ada sebelumnya, yaitu untuk dapat diangkat sebagai PPAT seorang Notaris harus mengikuti pendidikan dan pelatihan serta dinyatakan lulus yang diselenggarakan oleh BPN. Berdasarkan kenyataan ini, maka praktik implementasi tugas dan kewenangan Notaris, PPAT tetap tidak sama dan memiliki perbedaan seperti yang digambarkan sebagai berikut ini.

\section{a. Tugas dan Kewenangan Notaris}

Tugas dan kewenangan Notaris diatur dalam UUJN Nomor 2 Tahun 2014. Dalam Undang-Undang Nomor 2 Tahun 2014 Pasal 1 angka (1) dijelaskan bahwa "Notaris adalah pejabat umum yang berwenang untuk membuat akta otentik dan kewenangan lainnya sebagaimana dimaksud dalam undang-undang ini". 
Menurut Junaidi ${ }^{25}$, dikatakan bahwa tugas pokok dan kewenangan Notaris mengaca UUJN, yang pada pokoknya adalah membuat akta selain akta tanah dan risalah lelang. Sri Waryanti. ${ }^{26}$ menambahkan bahwa sebagai Notaris dirinya terikat dengan UUJN, maka tugas pokok dan kewenangan Notaris telah dijelaskan pada UUJN, yang menegaskan bahwa tugas pokoknya adalah membuat akta otentik, selain akta tanah dan risalah lelang. Hal senada juga dikatakan oleh Dodi Iskandar ${ }^{27}$ yang mengatakan bahwa tugas pokok, fungsi dan kewenangan Notaris sudah diatur dalam UUJN No. 2 Tahun 2014 tentang Jabatan Notaris.

Berdasarkan wawancara di atas diketahui bahwa tugas pokok, fungsi dan kewenangan Notaris telah diatur dalam UUJN No. 2 Tahun 2014. UndangUndang Nomor 30 Tahun 2004 yang telah diperbaharui dengan Undang-Undang Nomor 2 Tahun 2014 Pasal 15 menjelaskan bahwa kewenangan Notaris meliputi :

1) Notaris berwenang membuat akta otentik mengenai semua perbuatan, perjanjian, dan ketetapan yang diharuskan oleh peraturan perundang-undangan dan/atau yang dikehendaki oleh yang berkepentingan untuk dinyatakan dalam akta otentik.

2) Menjamin kepastian tanggal pembuatan akta, menyimpan akta, memberikan grosse, salinan dan kutipan akta

3) Mengesahkan tanda tangan dan menetapkan kepastian tanggal surat di bawah tangan dengan mendaftar dalam buku khusus

4) Membubuhkan surat-surat di bawah tangan dengan mendaftar dalam buku khusus

5) Membuat kopi dari asli surat-surat di bawah tangan, berupa salinan yang memuat uraian sebagaimana ditulis dan digambarkan dalam surat yang bersangkutan

6) Melakukan pengesahan kecocokan fotokopi dengan surat aslinya

7) Memberikan penyuluhan hukum sehubungan dengan pembuatan akta

8) Membuat akta yang berkaitan dengan pertanahan

9) Membuat akta risalah lelang.

Kewenangan Notaris tersebut dibatasi oleh ketentuan-ketentuan lain yakni:

\footnotetext{
${ }^{25}$ Wawancara dengan Junaidi, sebagaiNotaris di Kabupaten Kendal, tanggal 25 Januari 2018.

${ }^{26}$ Wawancara dengan Sri Waryanti.Mkn, sebagaiNotaris di Kabupaten Kendal, tanggal 26 Januari 2018.

${ }^{27}$ Wawancara dengan Wiwin Roswinanti, sebagaiNotaris di Kabupaten Kendal, tanggal 27 Januari 2018.
}

1) Tidak semua pejabat umum dapat membuat semua akta, tetapi seorang pejabat umum hanya dapat membuat akta-akta tertentu yang berdasarkan peraturan perundang-undangan (Pasal 1).

2) Notaris tidak berwenang membuat akta untuk kepentingan orang-orang tertentu (Pasal 53) Maksudnya, bahwa notaris tidak diperbolehkan membuat akta untuk diri sendiri, suami/istrinya, keluarga sedarah maupun keluarga semenda dari notaris, dalam garis keturunan lurus ke bawah tanpa batasan derajat serta dalam garis ke samping sampai dengan derajat ketiga, baik menjadi pihak untuk diri sendiri maupun melalui kuasa. Hal ini untuk mencegah terjadinya suatu tindakan memihak dan penyalahgunaan jabatan.

3) Notaris hanya berwenang untuk membuat akta otentik di wilayah hukum atau wilayah jabatannya. Di luar wilayah hukum atau wilayah jabatannya, maka akta yang dibuat tidak mempunyai kekuatan sebagai akta notariil (Pasal 17).

4) Notaris tidak boleh membuat akta, apabila notaris masih menjalankan cuti atau dipecat dari jabatannya. Notaris juga tidak boleh membuat akta, apabila notaris tersebut belum diambil sumpahnya (Pasal 11).

\section{b. Tugas dan Kewenangan PPAT}

Menurut Dodi Iskandar ${ }^{28}$ dikatakan bahwa tugas pokok PPAT adalah membuat akta tanah, dan karena yang bersangkutan adalah juga Notaris, maka ia juga memiliki kewenangan seperti yang diatur pada UUJN. Adapun Sri Waryanti. ${ }^{29}$ berpendapat bahwa karena PPAT berasal dari Notaris, maka dirinya selain terikat dengan tugas pokoknya sebagai PPAT sebagai membuat akta tanah, namun dirinya juga terikat dengan UUJN. Sebagai PPAT ia juga harus tunduk dengan kode etik yang dibuat oleh Ikatan PPAT dan juga kode etik yang dibuat oleh INI. Junaidi ${ }^{30}$ menambahkan bahwa tugas pokok, fungsi dan kewennagan PPAT sudah diatur tersediri dalam PP Nomor 37 Tahun 1998TentangPeraturan Jabatan Pejabat Pembuat Akta Tanah (PPAT) yang pelaksanaannya diatur pada Peraturan Kepala Badan Pertanahan NasionalNomor 23 Tahun 2009.

\footnotetext{
${ }^{28}$ Wawancara Wiwin Roswinanti, sebagaiNotaris di Kabupaten Kendal, tanggal 27 Januari 2018.

${ }^{29}$ Wawancara dengan Sri Waryanti.Mkn, sebagaiNotaris di Kabupaten Kendal, tanggal 26 Januari 2018.

${ }^{30}$ Wawancara dengan Junaidi, sebagaiNotaris di Kabupaten Kendal, tanggal 25 Januari 2018.
} 
Berdasarkan wawancara di atas diketahui bahwa tugas pokok dan kewenangan PPAT adalah membuat akta tanah. PPAT sudah dikenal sejak berlakunya PP Nomor 10/1961, dengan sebutan pejabat yang merupakan peraturan pelaksanaan UUPA, sebagai disebutkan dalam ketentuan Pasal 19 PP 10/1961 yang menyatakan bahwa :

Setiap perjanjian yang dimaksud memindahkan hak atas tanah memberikan sesuatu hak baru atas tanah, mengadaikan tanah atau meminjam uang dengan hak atas tanah sebagai tanggungan, harus dibuktikan dengan suatu akta yang dibuat oleh atau dihadapan pejabat yang ditunjuk oleh Menteri Agraria dan akta tersebut ditetapkan oleh Menteri Agraria.

Kemudian berdasarkan Undang-Undang Nomor 16 tahun 1985 tentang Rumah Susun, istilah PPAT mendapat pengukuhan dengan sebutan Pejabat Pembuat Akta Tanah sebagaimana dinyatakan dalam ketentuan Pasal 10 ayat (2) UU Nomor 16/1985, yaitu

Pemindahan hak sebagaimana dimaksudkan dalam ayat (1) dilakukan dengan akta Pejabat Pembuat Akta Tanah (PPAT) dan didaftarkan Kantor Agraria Kabupaten atau Kotamadya yang bersangkutan menurut ketentuan Peraturan Pemerintah sebagaimana dimaksudkan dalam pasal 19 Undang-Undang Nomor 5 tahun 1960.

Pengertian PPAT sebagai pejabat umum ditegaskan untuk pertama kalinya dalam UndangUndang Nomor 4 tahun 1996 tentang Hak Tanggungan atas tanahbeserta benda-benda yang berkaitan dengan tanah (selanjutnya disebut UUHT) sebagaimana dalam pasal 1 angka 4 UUHT yang berbunyi :

Pejabat Pembuat Akta Tanah, yang selanjutnya disebut PPAT adalah pejabat umum yang diberi wewenang untuk membuat akta pemindahan hak atas tanah, akta pembebanan hak atas tanah dan akta pemberian kuasa membebankan Hak Tanggungan menurut Peraturan PerundangUndangan yang berlaku.

Kemudian PP 24/1997 menegaskan kembali pengertian PPAT sebagai Pejabat Umum dimana dalam pasal 1 angka 24 PP 24/1997 dinyatakan bahwa "Pejabat Pembuat Akta Tanah selanjutnya disebut PPAT adalah Pejabat Umum yang diberi kewenangan untuk membuat akta-akta tanah tertentu".

Tugas dan wewenang Pejabat Pembuat Akta Tanah (PPAT) dapat dilihat dalam pasal 37 ayat (1) Peraturan Pemerintah Nomor 24 Tahun 1997 yaitu :

Peralihan hak atas tanah dan hak milik atau satuan rumah susun melalui jual beli, tukar menukar, hibah, pemasukan dalam perusahaan dan perbuatan hukum pemindahan hak lainnya, kecuali pemindahan hak melalui lelang hanya dapat didaftarkan jika dibuktikan dengan akta yang dibuat oleh PPAT yang berwenang menurut ketentuan perundangan yang berlaku.

Pejabat Pembuat Akta Tanah (PPAT) dalam membuat akta-akta yang dibuat dihadapannya haruslah sesuai dengan ketentuan undang-undang, hal ini harus diperhatikan dengan benar, karena jika terjadi keteledoran baik disengaja maupun tidak disengaja akan mendapat sanksi. Dalam pasal 96 ayat (2) PMNA/KBPN Nomor 3 Tahun 1997 jelas sekali bawah PPAT dalam membuat akta peralihan hak atas tanah haruslah mempergunakan formulir sesuai dengan ketentuan yang telah ditetapkan. Jika pada pasal ini diabaikan maka akta yang telah dibuat dihadapan Pejabat Pembuat Akta Tanah (PPAT) tidak dapat menjadi dasar pendaftaran di Kantor Pertanahan.

Sebelum membuat akta Pejabat Pembuat Akta Tanah (PPAT) terlebih dahulu harus melakukan pemeriksaan pada Kantor Pertanahan Kota/ Kabupaten perihal kesesuaian sertipikat hak atas tanah dengan data (buku tanah) yang ada dikantor pertanahan. Memeriksa dokumen-dokumen dari para pihak seperti Karta Tanda Penduduk (KTP), Kartu Keluarga (KK), Surat Nikah, Surat Cerai, Surat Kuasa bila dikuasakan, yang pada prinsipnya berkaitan dengan identitas diri, kewengan, kewajiban perpajakan (Pajak Bumi dan Bangunan, Pajak Penjual, Pejaka Pembeli) serta kelengkapan lain yang berkaitan dengan terpenuhinya syarat-syarata pembuatan akta.

Dalam pembuatan akta peralihan hak atas tanah oleh Pejabat Pembuat Akta Tanah (PPAT) haruslah dihadiri oleh sekurang-kurangnya 2 (dua) orang saksi yang memenuhi syarat bertindak sebagai seorang saksi sebagaimana tercantum dalam pasal 38 ayat (1) PP Nomor 24 tahun 1997.Dalam menjalan tugasnya PPAT harus memperhatikan ketentuan-ketentuan dalam pasal 39 PP Nomor 24 Tahun 1997, berikut dalam menjalankan ketentuan dalam pasal 40 PP Nomor 24 Tahun 1997.

PPAT apabila dalam menjalan tugasnya tidak memperhatikan ketentuan-ketentuan dalam PP Nomor 40 Tahun 1997, maka kepada Pejabat Pembuat Akta Tanah (PPAT) tersebut bisa dikenakan sanksi, dan hal ini jelas merugikan dirinya sendiri sebagaimana tercantum dalam Pasal 62 PP Nomor 24 Tahun 1997 yang berbunyi:

"Pejabat Pembuat Akta Tanah (PPAT) yang dalam menjalan tugasnya mengabaikan ketentuanketentuan sebagaimana dimaksud dalam pasal 38, Pasal 39, Pasal 40 serta ketentuan dan petunjuk yang diberikan oleh Menteri atau Pejabat yang 
ditunjuk dikenakan tindakan administrative berupa teguran terulis sampai pemberhentian dari jabatannya sebagai PPAT, dengan tidak mengurangi kemungkinan dituntut ganti kerugian oleh pihakpihak yang menderita kerugian yang diakibatkan oleh dibaiakannya ketentuan-ketentuan tersebut."

\section{Solusi Implementasi Tugas dan Kewenangan Notaris dan PPAT}

Menurut penulis ada satu hal yang dapat ditempuh untuk menghindari perbedaan implementasi tugas dan kewenangan Notaris antara yang ideal seperti UUJN 2014 dengan praktik di lapangan, yaitu: (1) Pemerintah melakukan revisi UUJN 2014 atau membuat Peraturan Presiden/ Keputusan Presiden.

Seperti yang telah diungkapkan di atas, bahwa menurut Undang-Undang Nomor 12 Tahun 2011 tentang PembentukanPeraturan PerundangUndangan telah mengatur tentang Jenis dan HierarkiPeraturan Perundang-undangan, kedudukan UUJN 2014 lebih tinggi dibandingkan dengan Peraturan Kepala BPN yang mengatur pengangkatan Notaris sebagai PPAT yang mengatur pengangkatan Notaris, maka agar implementasi UUJN 2014 Pasal 15 ayat (2) huruf (f) sesuai tidak menimbulkan perbedaan dengan kenyataan di lapangan, Pemerintah harus mencabut Peraturan Kepala BPN agar Notaris dapat secara otomatis sebagai PPAT sesuai ketentuan UUJN 2014 Pasal 15 ayat (2) huruf (f), dan juga secara otomatis sesuai ketentuan UUJN 2014 Pasal 15 ayat (2).

Pemerintah Merevisi UUJN 2014 atau Membuat Peraturan Pengganti Undang Undang. Seperti yang telah dijelaskan di muka bahwa implementasi UUJN 2014 Pasal 15 ayat (2) huruf (f) berbentur dengan Peraturan Kepala Badan Pertanahan NasionalNomor 23 Tahun 2009TentangPerubahan Atas Peraturan Kepala Badan Pertanahan NasionalNomor 1 Tahun 2006 Tentang KetentuanPelaksanaan Peraturan Pemerintah Nomor 37 Tahun 1998Tentang Peraturan JabatanPejabat Pembuat Akta Tanah, karena kenyataannya Notaris tidak secara otomatis sebagai PPAT.

Apabila Pemerintah tetap menghendaki bahwa pengangkatan Notaris sebagai PPAT harus melalui pendidikan dan pelatihan serta dinyatakan lulus yang diselenggarakan oleh BPN, maka hal yang dapat ditempuh oleh Pemerintah (Presiden) adalahMelakukan revisi terhadap UUJN 2014 dengan cara menambahkan pasal-pasal terkait persayaratan dan tata cara pengangkatan Notaris sebagai PPAT.

\section{SIMPULAN}

Berdasarkan hasil penelitian dan pembahasan seperti yang telah diuraikan pada bab sebelumnya, maka dapat ditarik kesimpulan sebagai berikut ini.

1. Implementasi tugas dan kewenangan Notaris dalam membuat akta yang berkaitan dengan pertanahan dipahami secara berbeda, karena: (1) Mengacu Pasal 15 ayat (2) huruf (f) UUJN 2014, maka Notaris secara otomatis adalah pejabat yang berwenang membuat akta tanah. Namun kenyataan di lapangan, Notaris tidak secara otomatis dapat menjadi Pejabat Pembuat Akta Tanah (PPAT); (2) Pada praktik di lapangan, Notaris dapat diangkat menjadi PPAT setelah mengikuti pendidikan dan pelatihan serta dinyatakan lulus yang diselenggarakan oleh BPN. Akan tetapi bahwa dalam hal Notaris membuat akta - akta yang berkaitan dengan pertanahan yang bukan merupakan kewajiban PPAT.

2. Kelemahan implementasi tugas dan kewenangan Notaris dalam membuat akta yang berkaitan dengan pertanahan adalah: (a) Konsep ideal implementasi tugas dan kewenangan Notaris menurut UUJN 2014 yaitu seorang Notaris sekaligus PPAT; Praktik implementasi tugas dan kewenagan Notaris di lapangan berbeda dengan UUJN 2014, karena Notaris diangkat menjadi PPAT setelah harus mengikuti pendidikan dan pelatihan serta dinyatakan lulus yang diselenggarakan oleh BPN.

3. Solusi terkait dengan implementasi tugas dan kewenangan Notaris antara yang ideal seperti UUJN 2014 dengan praktik di lapangan, yaitu: (a) Pemerintah melakukan revisi UUJN 2014 atau membuat Peraturan Pengganti Undang Undang.

\section{SARAN}

1. Pemerintah (Presiden) perlu segera mengambil sikap dan keputusan terkait dengan pro dan kotra atas perbedaan implementasi tugas dan kewenangan Notaris dalam bidang pertanahan.

2. Jabatan Notaris dan PPAT untuk saat ini perlu dipahami secara berbeda agar tidak menimbulkan kerancuan dalam memahami tugas pokok, fungsi dan kewenangan kedua jabatan tersebut.

3. Notaris dalam melaksanakan tugas pokok, fungsi dan kewenangannya selain harus berpedoman UUJN juga berpedoman pada Kode Etik Notaris yang dibuat oleh Ikatan Notaris Indonesia (INI). 


\section{DAFTAR PUSTAKA}

Achmad Ali. 2002. Menguak Tabir Hukum (Suatu Kajian Filosofis dan Sosiologis). Toko Gunung Agung, Jakarta.

Ali, Zainuddin, 2013,Metode Penelitian Hukum, Sinar Grafika, Jakarta.

Dominikus Rato. 2010. Filsafat Hukum Mencari, Menemukan, dan Memahami Hukum. Laksbang Pressindo. Yogyakarta.

Habib, Adjie, 2006, Tanggung Jawab Notaris Notaris sebagai Pejabat Publik. Mandar Maju, Bandung.

2009, Sekilas Dunia Notaris dan PPAT Indonesia (Kumpulan Tulisan). Mandar Maju, Bandung.

Irianto, Sulistyowati, 2009. "Memperkenalkan Studi Sosiolegal dan Implikasi Metodologisnya", Metode Penelitian Hukum-Konstelasi dan Refleksi, ed. Sulistyowati Irianto dan Shidarta, Jakarta.

M. Syamsudin, 2007,Operasional Penelitian Hukum, Raja Grafindo Persada, Jakarta.

Nur Basuki Winarmo. 2008. Penyalahgunaan wewenang dan tindak pidana korupsi. Laksbang Mediatama. Yogyakarta.

Peter Mahmud Marzuki. 2008. Pengantar IImu Hukum. Kencana. Jakarta.

Riduan Syahrani. 1999. Rangkuman Intisari IImu Hukum, Citra Aditya Bakti,Bandung.

Satjipto, Raharjo, 2006, Sisi-Sisi Lain dari Hukum di Indonesia, Penerbit Buku Kompas, Jakarta.
Setiawan, 1992,Aneka Masalah Hukum dan Hukum Perdata, Alumni, Bandung.

Sjaifurrachman dan Habib Adje, 2011, Aspek Pertanggungjawaban Notaris Dalam Pembuatan Akta, Mandar Maju, Bandung.

Soerjono Soekanto dan Sri Mamudji, 2006, Penelitian Hukum Normatif, Suatu Tinjauan Singkat, Raja Grafindo Persada, Jakarta.

Soerjono, Soekanto, 1986, Pengantar Penelitian Hukum, UI Press, Jakarta.

Soemitro, Ronny Hanitijo, 1988,Metode Penelitian Hukum, Ghalia Indonesia, Jakarta.

Sugiyono, 2010, Memahami Penelitian Kualitatif, Alfabeta, Bandung.

Tobing, G.H.S. Lumban , 1992, Peraturan Jabatan Notaris, Erlangga, Jakarta.

Undang - Undang Dasar Negara Republik Indonesia Tahun 1945

Kitab Undang Undang Hukum Perdata.

Undang-Undang Nomor 2 Tahun 2014 tentang Perubahan Atas Undang-Undang Nomor 30 Tahun 2004 Jabatan Notaris.

PeraturanPemerintah Nomor 37 Tahun 1998 tentang Peraturan Jabatan Pejabat Pembuat Akta Tanah.

Peraturan Pemerintah RI Nomor 10 Tahun 2006 tentang Badan Pertanahan Nasional.

Peraturan Pemerintah Nomor 37 Tahun 1998 Tentang Peraturan Jabatan Pejabatan Pembuat Akta Tanah.

https://agenta08.wordpress.com/2009/01/24/bebera pa-pengumpulan-data-teknik-pengamatanwawancara-dan-angket/ 